\title{
Synthesis of Rumphellaone A and Hushinone by a Gold-Catalyzed [2 + 2] Cycloaddition
}

\author{
Beatrice Ranieri, ${ }^{\dagger, \S}$ Carla Obradors, ${ }^{\dagger, \S}$ Mauro Mato, ${ }^{\dagger}$ and Antonio M. Echavarren ${ }^{*}, \dagger, \dagger$ \\ ${ }^{\dagger}$ Institute of Chemical Research of Catalonia (ICIQ), Barcelona Institute of Science and Technology, Av Països Catalans 16, 43007 \\ Tarragona, Spain \\ ${ }^{\text {*} D e p a r t a m e n t ~ d e ~ Q u i ́ m i c a ~ A n a l i ́ t i c a ~ i ~ Q u i ́ m i c a ~ O r g a ̀ n i c a, ~ U n i v e r s i t a t ~ R o v i r a ~ i ~ V i r g i l i, ~ C / M a r c e l-l i ~ D o m i n g o ~ s / n, ~} 43007$ Tarragona, \\ Spain
}

Supporting Information

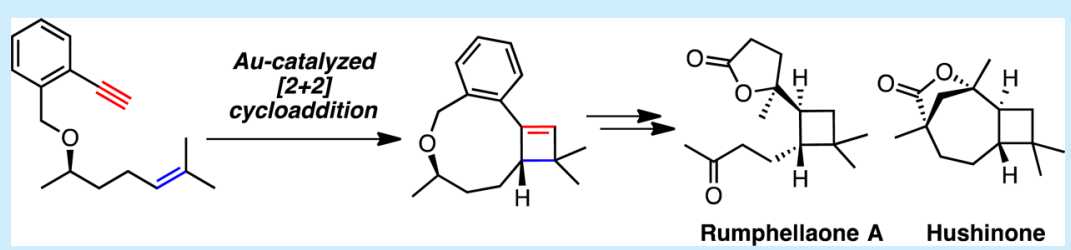

ABSTRACT: The enantioselective total synthesis of rumphellaone A has been accomplished in 12 steps via a diastereoselective gold(I)-catalyzed [2 +2] macrocyclization of a 1,10-enyne as the key step to build the cyclobutene moiety. This concise approach has also led to the total synthesis of husinone.

$\mathrm{R}$ umphellaone A (1) is a 4,5-seco-caryophyllane sesquiterpenoid possessing an unprecedented $\gamma$-lactone moiety that shows citotoxicity against human $\mathrm{T}$-cell acute lymphoblastic leukemia tumor cells $\left(\mathrm{IC}_{50}=12.6 \mu \mathrm{g} / \mathrm{mL}\right) .{ }^{1}$ This sesquiterpenoid was isolated from Rumphella antipathies, a gorgonian coral that has produced several other caryophyllane and clovane sesquiterpenes (Figure 1). ${ }^{2}$ Isolation of $402 \mathrm{~g}$ of wet $R$.
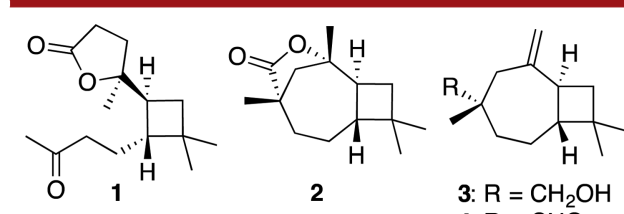

3: $\mathrm{R}=\mathrm{CH}_{2} \mathrm{OH}$

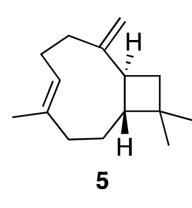

Figure 1. Rumphellaone A, hushinone, and other related $\beta$ caryophyllene natural products.

antipathies yielded only $0.9 \mathrm{mg}$ of $1{ }^{1}$ Hushinone (2), birkenol (3), and birkenal (4) are noresesquiterpenoids identified in the essential oils obtained from the buds of Betula pubescens ssp. czerepanovii (mountain birch) and Betula pubescens ssp. Pubescens (white birch). ${ }^{3}$ Biosynthetically, the unusual carbon skeleton of $2-4$ was proposed to be the result of a formal $[1,3]$ sigmatropic rearrangement of $\beta$-caryophyllene (5), followed by an oxidative degradation. ${ }^{4}$ To date, there is no report on the pharmacological properties of compounds $2-4 .^{5}$

The total syntheses of rumphellaone A $(1)^{6}$ and hushinone $(2)^{7}$ have been reported by the group of Kuwahara by sequences involving 18 and 22 steps, respectively, from commercially available methyl isobutyrate through a common intermediate.

As part of our work on the application of gold catalysis for the total synthesis $^{8}$ of relevant natural compounds, ${ }^{9}$ we envisioned that a straightforward synthesis of rumphellaone A (1) and hushinone (2) could be performed by building the tetrasubstituted cyclobutane moiety via a gold(I)-catalyzed [2+ 2] macrocyclization of 1,10 -enyne 6 (Scheme 1$).{ }^{10}$ This

Scheme 1. Retrosynthetic Approach to Rumphellaone A
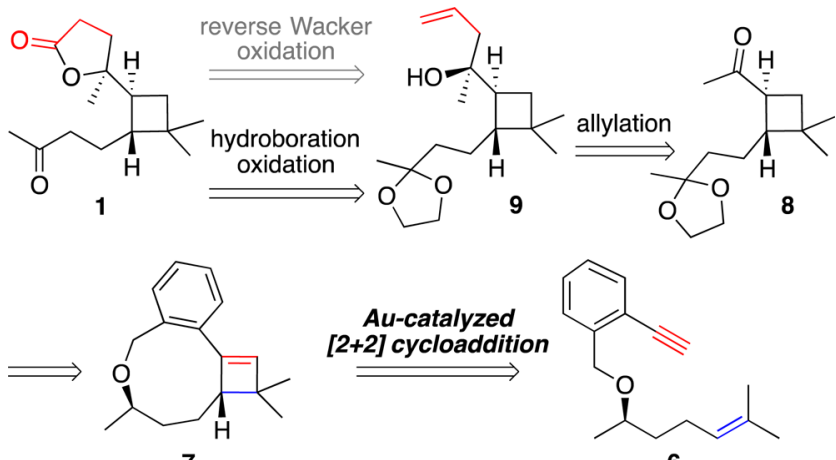

diastereoselective transformation is a useful and novel approach for the synthesis of natural products containing the cyclobutene moiety. We expected that the resulting cycloadduct 7 could be converted into key intermediate 8 through hydrogenation of the double bond, hydrogenolysis of the benzylic ether, and oxidative cleavage of the aryl ring. The end-game of the synthesis would involve a diastereoselective allylation of 8 followed by either a reverse Wacker-type oxidation or a hydroboration-oxidation to form the $\gamma$-lactone.

Received: February 18, 2016

Published: March 14, 2016 
First, we examined the diastereoselectivity in the cyclization of rac-6 to form 9-membered ring rac-7 using different gold(I) catalysts. Using $3 \mathrm{~mol} \%$ of catalyst $\mathbf{A}$, the complex we used in our initial methodological work, ${ }^{10 a}$ a $5: 1$ mixture of diastereomers was obtained in modest yield (Table 1, entry

Table 1. Gold(I)-Catalyzed $[2+2]$ Cycloaddition of 1,10Enyne 9

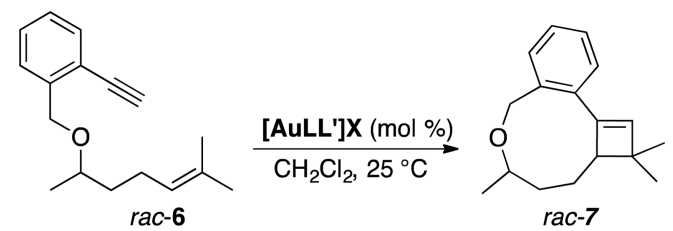

$\begin{array}{cccr}\text { entry } & \text { catalyst (mol \%) } & \text { yield }^{a}(\%) & \mathrm{dr}^{b} \\ 1^{c} & \text { A (3) } & 51 & 5: 1 \\ 2^{d} & \text { A (5) } & 68 & 5.6: 1 \\ 3^{d} & \text { B (5) } & 68 & 5.7: 1 \\ 4^{d} & \text { C (5) } & 70 & 7: 1 \\ 5^{d} & \text { D (5) } & 80 & 9: 1\end{array}$

${ }^{a}$ Isolated yields. ${ }^{b}$ Determined by ${ }^{1} \mathrm{H}$ NMR. ${ }^{c}$ Reaction performed for $19 \mathrm{~h} .{ }^{d}$ Reaction performed for $24 \mathrm{~h}$.

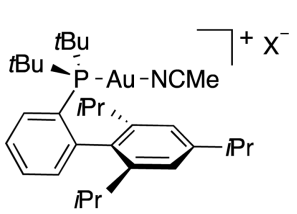

A: $X=\mathrm{SbF}_{6}$

B: $\mathrm{X}=\mathrm{BAr}_{4} \mathrm{~F}$

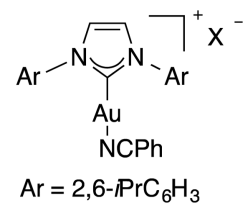

C: $X=\mathrm{SbF}_{6}$
1 ), which could be improved to $68 \%$ by increasing the catalyst loading to $5 \mathrm{~mol} \%$ (Table 1, entry 2). Identical results were obtained using catalyst $\mathbf{B}$ with $\mathrm{BAr}_{4}{ }^{\mathrm{F}}$ as the anion ${ }^{10 \mathrm{~b}}$ (Table 1, entry 3). In this case, hydration of the alkyne to form the corresponding methyl ketone was a significant side reaction (ca. $15 \%)$. Better yields were obtained by using gold(I) complexes $\mathbf{C}$ and $\mathbf{D}$ bearing IPr as the ligand (Table 1 , entries 4 and 5). The optimal result $(80 \%, 9: 1 \mathrm{dr})$ was achieved with complex D with $\mathrm{BAr}_{4}{ }^{\mathrm{F}}$ as the anion (Table 1 , entry 5 ).

With these results in hand, we embarked in the total synthesis of rumphellaone A (1) starting from $(R)-6$, which was prepared on a multigram scale from commercially available $(R)$ 6-methylhept-5-en-2-ol by alkylation with $o$-iodobenzyl bromide, Sonogashira coupling with trimethylsilyl acetylene, and TMS deprotection (59\% for the three steps) (Scheme 2). ${ }^{11}$ The major diasteromer of 7 was obtained with 97.3:2.7 er in a $75 \%$ average yield. We then explored different conditions for the stereoselective reduction of the cyclobutene double bond ${ }^{12}$ of 7. The most practical solution consisted in performing a Pdcatalyzed hydrogenation of the double bond and simultaneous hydrogenolysis of the benzylic ether to furnish alcohol $\mathbf{1 0}$ in good yield and 2.4:1 diastereoselectivity in favor of the cis isomer, postponing the installation of the correct relative configuration to a later stage in the synthesis. Oxidative cleavage of the aryl ring led to cyclobutane carboxylic acid 11 in $89 \%$ yield, which after methylation and ketone protection gave acetal-protected ester $\mathbf{1 2}$ in almost quantitative yield. At this point, the required trans configuration at the cyclobutane ring was achieved via epimerization at the $\alpha$-position of the ester in a one-pot epimerization-hydrolysis sequence, ${ }^{13}$ yielding pure trans-13 in $86 \%$. It is worth mentioning that no chromato-
Scheme 2. Synthesis of Allylic Alcohol 9
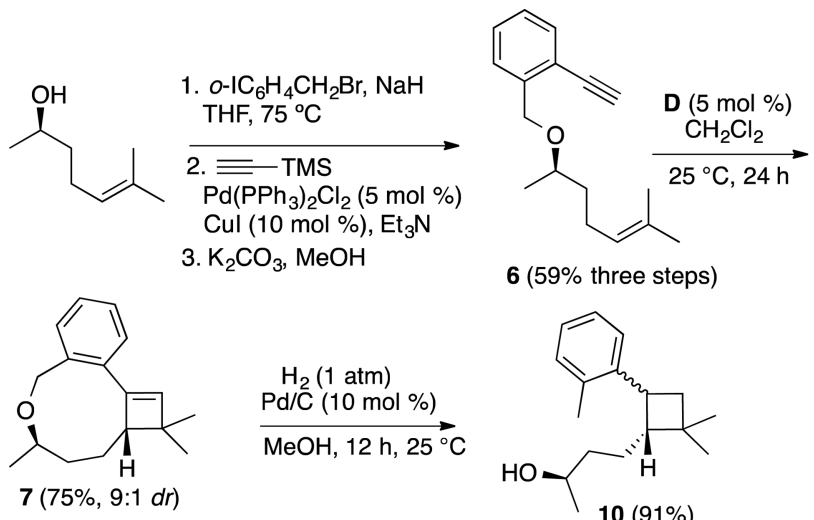

6 (59\% three steps)
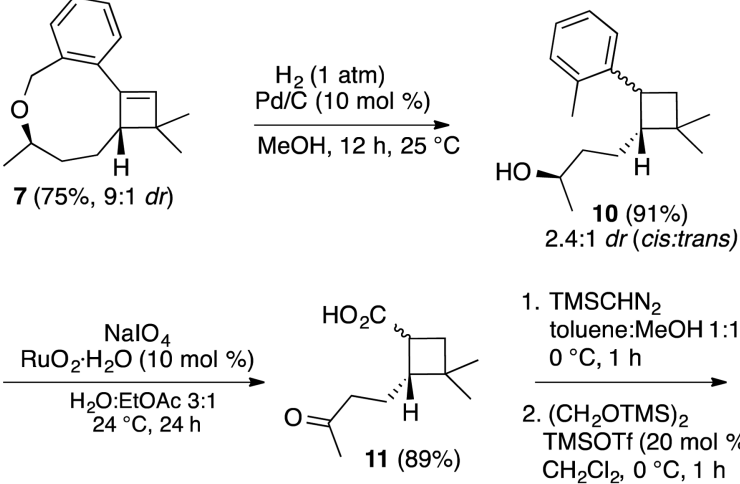

1. $\mathrm{TMSCHN}_{2}$ toluene:MeOH 1:1 $0{ }^{\circ} \mathrm{C}, 1 \mathrm{~h}$

2. $\left(\mathrm{CH}_{2} \mathrm{OTMS}\right)_{2}$ TMSOTf (20 $\mathrm{mol} \%)$ $\mathrm{CH}_{2} \mathrm{Cl}_{2}, 0^{\circ} \mathrm{C}, 1 \mathrm{~h}$
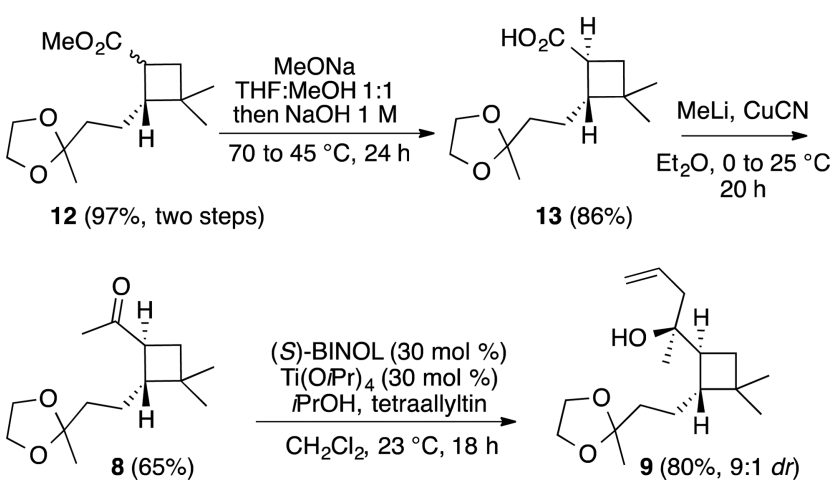

graphic purification was required in the transformation of $\mathbf{1 1}$ into 13. Treatment of 13 with $\mathrm{MeLi}$ and $\mathrm{CuCN}$ gave methyl ketone $8{ }^{14}$ Initially we attempted a series of diastereoselective allylation reactions ${ }^{15}$ in order to obtain preferentially the tertiary allylic alcohol 9 with $S$-configuration at the newly formed stereocenter. However, mixtures of diastereomers with poor selectivity were always obtained. In order to circumvent this problem, we opted for an asymmetric allylation reaction exploiting the in situ formation of a (BINOLate)titanium complex. ${ }^{16}$ Using (S)-BINOL, this robust methodology delivered the desired tertiary alcohol 9 in 80\% yield with 9:1 diastereoselectivity.

In our initial retrosynthetic plan, we planned to use the reverse Wacker oxidation of allylic alcohol 9 to form the final $\gamma$ lactone (Scheme 3). The product was a lactol that could be further oxidized to the desired lactone of rumphellaone A (1) using PCC. ${ }^{17}$ However, together with the free lactol, we also obtained its tert-butyl acetal, which had to be cleaved before the oxidation to the lactone using TFA, which added an extra step to the synthesis. This three-step sequence was finally substituted with a very efficient one-pot hydroborationoxidation procedure ${ }^{18}$ that delivered rumphellaone $\mathrm{A}(\mathbf{1})$ in $53 \%$ yield $\left([\alpha]_{\mathrm{D}}{ }^{25}+65.6\left(\mathrm{CHCl}_{3}, c 1.11\right)^{19}\left(\right.\right.$ lit. $^{6 \mathrm{a}}[\alpha]_{\mathrm{D}}{ }^{30}+75.8$ $\left.\left(\mathrm{CHCl}_{3}, c 1.11\right)\right)$.

Furthermore, we completed a total synthesis of hushinone (2) from synthetic rumphellaone A (1). Thus, rumphellaone A (1) was first subjected to Baeyer-Villiger oxidation to give 
Scheme 3. Synthesis of Rumphellaone A (1) by Oxidative Cyclization
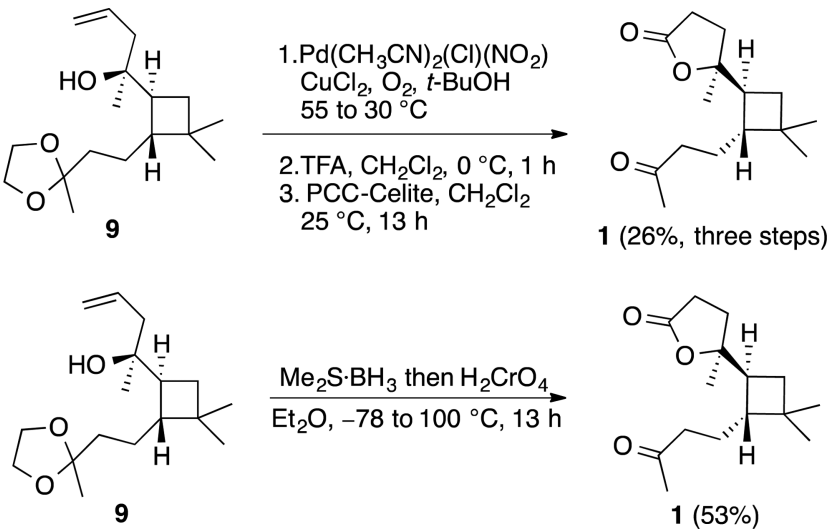

acetate $\mathbf{1 4}$ (Scheme 4). Intermediate $\mathbf{1 4}$ was treated with LDA and $\mathrm{MeI}$ to give the corresponding $\alpha$-methyl lactone, ${ }^{6 \mathrm{~b}}$ with

Scheme 4. Synthesis of Hushinone (2)

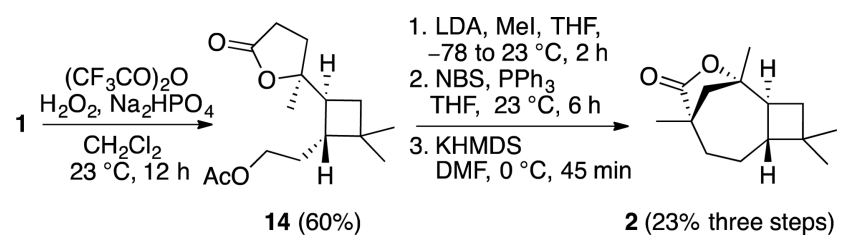

concomitant cleavage of the acetate to form the primary alcohol. Finally, reaction with $\mathrm{NBS} / \mathrm{PPh}_{3}$ and diastereoselective intramolecular alkylation furnished (+)-hushinone (2).

In summary, we have completed the total synthesis of (+)-rumphellaone A (1) and (+)-hushinone (2) in 12 (ca. 8\% yield) and 16 steps (ca. $1.1 \%$ yield), ${ }^{20}$ respectively, from commercially available alcohol (R)-6-methylhept-5-en-2-ol by using a diastereoselective gold(I)-catalyzed $[2+2]$ macrocyclization as the key step. This is the first application of the [2 +2 ] cycloaddition of alkynes with alkenes catalyzed by gold(I) in total synthesis.

\section{ASSOCIATED CONTENT}

\section{S Supporting Information}

The Supporting Information is available free of charge on the ACS Publications website at DOI: 10.1021/acs.orglett.6b00473.

Experimental procedures and characterization data for compounds (PDF)

\section{AUTHOR INFORMATION}

\section{Corresponding Author}

*E-mail: aechavarren@iciq.es.

Author Contributions

${ }^{\S}$ B.R. and C.O. contributed equally

Notes

The authors declare no competing financial interest.

\section{ACKNOWLEDGMENTS}

We thank MINECO (Severo Ochoa Excellence Accreditation 2014-2018 (SEV-2013-0319) and CTQ2013-42106-P), the

European Research Council (Advanced Grant No. 321066), the AGAUR (2014 SGR 818), the Marie Curie program (Postdoctoral Fellowship 658256-MSCA-IF-EF-ST to B.R.) and the ICIQ Foundation.

\section{REFERENCES}

(1) (a) Chung, H.-M.; Chen, Y.-H.; Lin, M.-R.; Su, J.-H.; Wang, W.H. Tetrahedron Lett. 2010, 51, 6025-6027. (b) Chung, H.-M.; Wang, W.-H.; Hwang, T.-L.; Li, J.-J.; Fang, L.-S.; Wu, Y.-C.; Sung, P.-J. Molecules 2014, 19, 12320-12327.

(2) Chung, H.-M.; Wang, W.-H.; Hwang, T.-L.; Fang, L.-S.; Wen, Z.H.; Chen, J.-J.; Wu, Y.-C.; Sung, P.-J. Mar. Drugs 2014, 12, 5856-5863 and references therein.

(3) Klika, K. D.; Demirci, B.; Salminen, J.-P.; Ovcharenko, V. V.; Vuorela, S.; Başer, K. H. C.; Pihlaja, K. Eur. J. Org. Chem. 2004, 2004, 2627-2635.

(4) (a) Ohloff, G.; Uhde, G.; Schulte-Elte, K.-H. Helv. Chim. Acta 1967, 50, 561-570. (b) Schulte-Elte, K.-H.; Ohloff, G. Helv. Chim. Acta 1971, 54, 370-397. (c) Shafi, P. M.; Tava, A. Acta Pharm. 1999, 49, 133-135. (d) Chou, S.-T.; Lai, C.-P.; Lin, C.-C.; Shih, Y. Food Chem. 2012, 134, 262-268.

(5) Isidorov, V. A.; Bagan, R.; Szczepaniak, L.; Swiecicka, I. Open Chem. 2015, 13, 125-137.

(6) (a) Hirokawa, T.; Nagasawa, T.; Kuwahara, S. Tetrahedron Lett. 2012, 53, 705-706. (b) Hirokawa, T.; Kuwahara, S. Tetrahedron 2012, $68,4581-4587$.

(7) Hirokawa, T.; Kuwahara, S. Eur. J. Org. Chem. 2013, 2013, 27802782.

(8) For reviews on the application of gold catalysis to the synthesis of natural product, see: (a) Fürstner, A. Chem. Soc. Rev. 2009, 38, 32083221. (b) Fürstner, A. Acc. Chem. Res. 2014, 47, 925-938. (c) Zhang, Y.; Luo, T.; Yang, Z. Nat. Prod. Rep. 2014, 31, 489-503. (d) Pflästerer, D.; Hashmi, A. S. K. Chem. Soc. Rev. 2016, 45, 1331-1367.

(9) (a) Jiménez-Núñez, E.; Molawi, K.; Echavarren, A. M. Chem. Commun. 2009, 7327-7329. (b) Molawi, K.; Delpont, N.; Echavarren, A. M. Angew. Chem. 2010, 122, 3595-3597; Angew. Chem., Int. Ed. 2010, 49, 3517-3519. (c) Gaydou, M.; Miller, R. E.; Delpont, N.; Ceccon, J.; Echavarren, A. M. Angew. Chem., Int. Ed. 2013, 52, 63966399. (d) Carreras, J.; Livendahl, M.; McGonigal, P. R.; Echavarren, A. M. Angew. Chem., Int. Ed. 2014, 53, 4896-4899. (e) Homs, A.; Muratore, M.; Echavarren, A. M. Org. Lett. 2015, 17, 461-463.

(10) (a) Obradors, C.; Leboeuf, D.; Aydin, J.; Echavarren, A. M. Org. Lett. 2013, 15, 1576-1579. (b) Homs, A.; Obradors, C.; Leboeuf, D.; Echavarren, A. M. Adv. Synth. Catal. 2014, 356, 221-228. (c) Intermolecular $[2+2]$ cycloaddition of alkynes with alkynes: LópezCarrillo, V.; Echavarren, A. M. J. Am. Chem. Soc. 2010, 132, 92929294.

(11) See the Supporting Information.

(12) (a) Posner, G. H.; Switzer, C. J. Am. Chem. Soc. 1986, 108, 1239-1244. (b) Iwasaki, K.; Wan, K. K.; Oppedisano, A.; Crossley, S. W. M.; Shenvi, R. A. J. Am. Chem. Soc. 2014, 136, 1300-1303. (c) Shvartsbart, A.; Smith, A. B., III J. Am. Chem. Soc. 2015, 137, 3510-3519. (d) Oikawa, Y.; Tanaka, T.; Yonemitsu, O. Tetrahedron Lett. 1986, 27, 3647-3650. (e) Schrems, M. G.; Neumann, E.; Pfaltz, A. Angew. Chem., Int. Ed. 2007, 46, 8274-8276. (f) Weise, C. F.; Pischl, M. C.; Pfaltz, A.; Schneider, C. J. Org. Chem. 2012, 77, 14771488.

(13) Gutekunst, W. R.; Gianatassio, R.; Baran, P. S. Angew. Chem., Int. Ed. 2012, 51, 7507-7510.

(14) Genna, D. T.; Posner, G. H. Org. Lett. 2011, 13, 5358-7361.

(15) (a) Wada, R.; Oisaki, K.; Kanai, M.; Shibasaki, M. J. Am. Chem. Soc. 2004, 126, 8910-8911. See the Supporting Information for racemic conditions. (b) Schneider, U.; Kobayashi, S. Angew. Chem., Int. Ed. 2007, 46, 5909-5912. (c) Fandrick, K. R.; Fandrick, D. R.; Gao, J. J.; Reeves, J. T.; Tan, Z.; Li, W.; Song, J. J.; Lu, B.; Yee, N. K.; Senanayake, C. H. Org. Lett. 2010, 12, 3748-3751. (d) Williams, F. J.; Grote, R. E.; Jarvo, E. R. Chem. Commun. 2012, 48, 1496-1498. 
(16) (a) Casolari, S.; D’Addari, D.; Tagliavini, E. Org. Lett. 1999, 1, 1061-1063. (b) Waltz, K. M.; Gavenonis, J.; Walsh, P. J. Angew. Chem. 2002, 114, 3849-3852. (c) Waltz, K. M.; Gavenonis, J.; Walsh, P. J. Angew. Chem., Int. Ed. 2002, 41, 3697-3699. (d) Kim, J. G.; Waltz, K. M.; Garcia, I. F.; Kwiatkowski, D.; Walsh, P. J. J. Am. Chem. Soc. 2004, $126,12580-12585$.

(17) Pandey, S. K.; Ramana, C. V. J. Org. Chem. 2011, 76, 23152318.

(18) Mandal, A. K.; Mahajan, S. W. Synthesis 1991, 1991, 311-313. (19) Chiral HPLC analysis shows a 97.3:2.7 er for our synthetic rumphellaone $\mathrm{A}(\mathbf{1})$.

(20) (a) The total synthesis reported by Kuwahara for (+)-rumphellaone A $(1)^{6}$ and (+)-hushinone $(2)^{7}$ proceeded in ca. $2 \%$ and $3 \%$ overall yield from methyl isobutyrate, respectively. (b) Preparation of 2,2-dimethylpent-4-en-1-ol from methyl isobutyrate: Jeong, Y.; Kim, D.-G.; Choi, Y.; Ryu, J.-S. Org. Biomol. Chem. 2011, 9, 374-378. 